\title{
Discussion: Investigation of dam incidents and failures
}

Alan L. Warren DIC, MSC, CEng, FICE

Chief Engineer (Dams), Halcrow Group Ltd, Swindon, UK

M. F. Kennard BSC, FICE

Consulting Engineer, UK
Eddie N. Bromhead MSC, PhD, DIC, MICE

Professor, Kingston University, Kingston upon Thames, UK

\section{Contribution by M. F. Kennard and E. N. Bromhead}

The paper by Warren (2011) refers to the failure of Carsington dam at a late stage in its construction in 1984, and to the owners then seeking advice from Babtie Shaw and Morton and Professor Alec Skempton immediately following the failure. A reader may form a different view of events from a discussion on other papers on the failure published in Géotechnique (Skempton and Vaughan, 1994). An investigation and report into the stability of the embankment dam was made some 6 months before the failure, and is described by Kennard and Bromhead (2000) as a means by which the eventual failure could easily have been averted. This technical report on stability was undertaken on instructions from the contractor in the light of movements detected in the embankment late in the construction season the previous year. The report was immediately disclosed to both the consulting engineers and the water authority.

The report highlighted facts and evidence that showed that the design was inadequate, found by means of routine limit equilibrium analyses based on the consulting engineers' own quoted surfaces involving both fill and foundation. Some complexity arose because the shear strength parameters appeared to have little basis in measurements and the pore pressures assumed in design had not materialised as predicted. It was therefore necessary to reassess the shear strength data and make use of actual (i.e. site-measured) pore water pressures projected to the point of completion of the earthworks in order to make a prediction of ultimate stability. When this was done, the analysis revealed that the critical factor of safety was well below that generally accepted for earth dams and was, indeed, close to failure. This report to the contractor concluded that 'further analyses are necessary and a revised design is essential, so that the embankment can be completed in 1984 with safety and confidence. At least one inclinometer penetrating the fill and the foundation will give any warning of instability in a quicker and more satisfactory manner than a method solely based on analysis'.

No effective action was taken either by the water authority or their consulting engineers, although level stations on the upstream face of the embankment dam showed movement during the winter. Despite requests from the contractor, no meetings or discussions were held to discuss the report. However, the form of contract employed effectively muzzled the contractor (Skempton and Vaughan, 1994).

\section{REFERENCES}

Kennard MF and Bromhead EN (2000) Carsington dam - the near-miss which became a bullseye. Proceedings of 2nd Forensic Congress, San Juan, Puerto Rico. ASCE, Reston, VA, pp. 102-111.

Skempton AW and Vaughan PR (1994) Discussion of papers 'The failure of Carsington Dam' by A. W. Skempton and P. R. Vaughan (1993) Géotechnique 43, No. 1, pp. 151-173 and 'Investigation of the failure of Carsington Dam' by G. Rocke (1993) Géotechnique 43, No. 1, pp. 175-180. Géotechnique 44(4): 719-739.

Warren AL (2011) Investigation of dam incidents and failures. Proceedings of the Institution of Civil Engineers - Forensic Engineering 164(1): 33-41, doi 10.1680/feng.2011.164.1.33.

\section{WHAT DO YOU THINK?}

To discuss this paper, please email up to 500 words to the editor at journals@ice.org.uk. Your contribution will be forwarded to the author(s) for a reply and, if considered appropriate by the editorial panel, will be published as discussion in a future issue of the journal.

Proceedings journals rely entirely on contributions sent in by civil engineering professionals, academics and students. Papers should be 2000-5000 words long (briefing papers should be 1000-2000 words long), with adequate illustrations and references. You can submit your paper online via www.icevirtuallibrary.com/content/journals, where you will also find detailed author guidelines. 